\title{
Intra-annual and long-term patterns in the reproductive cycle of giant scallops Placopecten magellanicus (Bivalvia: Pectinidae) from Passamaquoddy Bay, New Brunswick, Canada
}

\author{
G. J. Parsons ${ }^{1, *}$, S. M. C. Robinson ${ }^{2}$, R. A. Chandler ${ }^{2}$, L. A. Davidson ${ }^{3}$, \\ M. Lanteigne ${ }^{3}$, M. J. Dadswell ${ }^{4}$ \\ ${ }^{1}$ Department of Zoology, University of Guelph, Guelph, Ontario, Canada N1G 2W1 \\ ${ }^{2}$ Department of Fisheries and Oceans, Biological Station, St. Andrews, New Brunswick, Canada E0G 2X0 \\ ${ }^{3}$ Department of Fisheries and Oceans, PO Box 5030, Moncton, New Brunswick, Canada E1C 9B6 \\ ${ }^{4}$ Department of Biology, Acadia University, Wolfville, Nova Scotia, Canada B0P 1X0
}

\begin{abstract}
The reproductive cycle of giant scallops Placopecten magellanicus was examined over a 13 yr period from 1978 to 1990 at several sites within Passamaquoddy Bay, New Brunswick. Gonosomatic index (GSI) and gonad weight were obtained from scallops sampled approximately monthly. From 1985 to 1990 , samples were collected every 2 wk during the gonad ripening and about weekly during the spawning period. Scallops in Passamaquoddy Bay had one main spawning period between July and September, with peak spawning occurring during August. Spawning was not a continuous and complete process, but was intermittent, with 2 to 3 spawning events. There was concordance between these spawning events and the lunar/tidal cycle, suggesting a tidally related spawning cue Spawning was highly synchronous within local populations, between sexes, and within the bay. Onset. duration, and periodicity of spawning were also similar between years. The long-term GSI pattern and maximum level in the reproductive cycle of giant scallops from Passamaquoddy Bay were annually consistent. Therefore, it appears that in Passamaquoddy Bay, changes in potential reproductive output (independent of size and numbers) may not be as important in the determination of recruitment for scallops as factors operating at other life-history stages.
\end{abstract}

\section{INTRODUCTION}

The giant scallop is a gonochoristic species (separate sexes) with 'broadcast' spawning. The general features of reproductive biology, annual gametogenic cycle, and reproductive production and effort in giant scallops Placopecten magellanicus (Gmelin, 1791) have been described (Naidu 1970, Robinson et al. 1981, MacDonald \& Thompson 1985, Beninger 1987, MacDonald et al 1987). Recent papers by MacDonald \& Thompson (1985, 1986), Barber et al. (1988) and Dupaul et al. (1989) have compared the reproductive output of scallops between different sites and different

\footnotetext{
- Present address: Biological Station, Department of Fisheries and Oceans, St. Andrews, New Brunswick, Canada EOG 2X0
}

years. While environmental variables, especially food and temperature, have been shown to influence reproduction in the giant scallop (MacDonald \& Thompson 1985, 1988, MacDonald et al. 1987), the environmental cues which may be responsible for the initiation of the various reproductive events, especially spawning, are less well known (Robinson et al. 1981, MacDonald \& Thompson 1988).

Throughout its range, from the Gulf of St. Lawrence south to Cape Hatteras (Posgay 1957), the annual major spawning event of the giant scallop occurs from August to October (Stevenson 1936, Posgay \& Norman 1958, Naidu 1970, MacKenzie et al. 1978, Robinson et al. 1981, Beninger 1987, Barber et al. 1988). Exceptions to the late summer to autumn spawning of giant scallops include a minor June-July spawning among 
scallops from (1) western Newfoundland (Naidu 1970), (2) a deep-water population in the Gulf of Maine (Barber et al. 1988), and (3) off New Jersey (MacDonald \& Thompson 1988). More recently, a semiannual spawning cycle (spring and autumn) was described for Placopecten magellanicus from the midAtlantic region (Dupaul et al. 1989, Schmitzer et al. 1991) and may occur on Georges Bank (Dibacco 1991). While much is known about its reproductive biology and physiological ecology, the factors related to the reproductive success or recruitment of this species remain uncertain.

Few long-term studies of the reproductive cycle in marine molluscs exist (Loosanoff 1965, Giese 1969, Seed 1975), partly due to the difficulties of conducting long-term research (Grant \& Tyler 1983). Studies on the reproductive cycle of scallops have generally been only 1 to 3 yr in duration (Mason 1958a, Sastry 1970. Anseli 1974, Shafee \& Lucas 1980, Dredge 1981, Robinson \& Breese 1984, MacDonald \& Thompson 1986). Long-term studies of reproduction provide ecologically significant insights about intrapopulation variation in reproductive output, timing and duration of spawning, and may yield predictive capabilities concerning recruitment (Seed 1976, MacDonald \& Thompson 1985). Likewise, few studies have examined the intra-annual spawning variation in scallops with sufficient resolution to describe any detailed spawning patterns (e.g. Bricelj et al. 1987) or to elucidate any potential spawning cues.

Data have been collected on the reproductive cycle of giant scallops from Passamaquoddy Bay since 1978, and our objectives in this study were to examine the long-term and intra-annual variation in the reproductive cycle and spawning synchrony of giant scallops Placopecten magellanicus.

\section{MATERIAL AND METHODS}

Study area. Giant scallops Placopecten magellanicus were obtained from 6 sites within Passamaquoddy

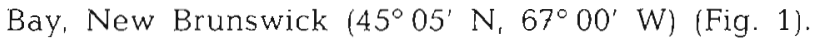
Passamaquoddy Bay has semi-diurnal tides with a maximum tidal range of $8.3 \mathrm{~m}$, annual mean temperature of $7^{\circ} \mathrm{C}$ (range 0 to $12^{\circ} \mathrm{C}$ ) and a well-mixed water column (Trites \& Garrett 1983). Substrate of the local scallop beds consisted mainly of gravel, mud, and silt. Average depths of the beds were $10 \mathrm{~m}$ for Navy Island, Tongue Shoal, Joe's Point, and Hill's Point and $60 \mathrm{~m}$ for Mascarene and Western Passage.

Sampling. Scallops were sampled approximately monthly from 1978 to 1984 at the Navy Island and Mascarene sites (Table 1). Navy Island and 4 other sites were sampled at different times from 1985 to 1990

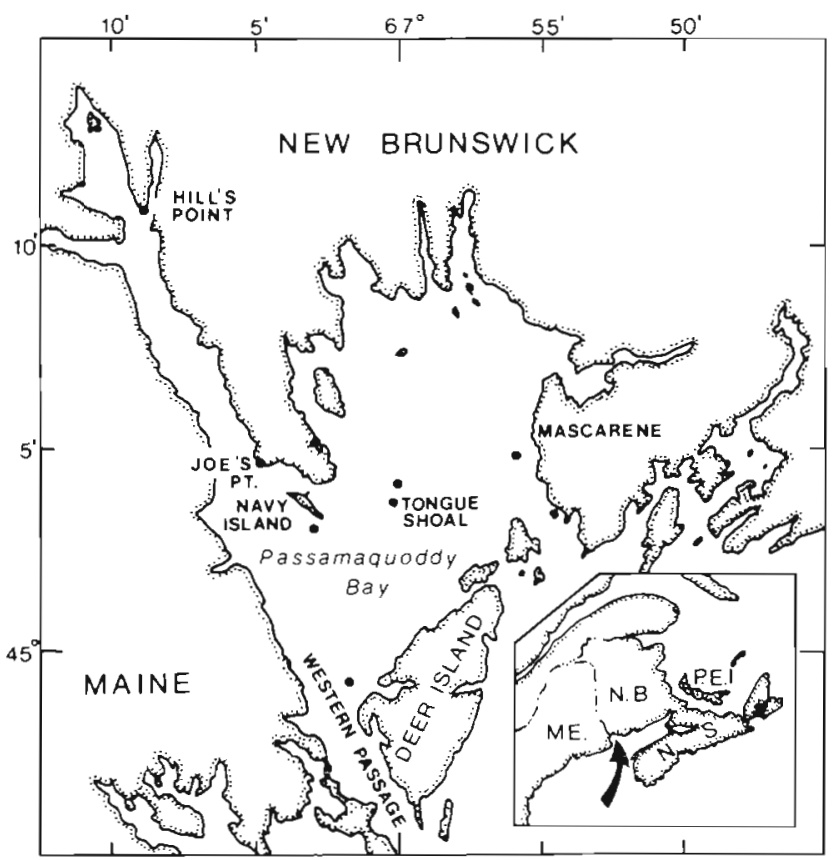

Fig. 1. Passamaquoddy Bay, indicating location of sampling sites (Hill's Point, Joe's Point, Navy Island, Tongue Shoal, Mascarene, Western Passage). Inset: Passamaquoddy Bay in relation to eastern Canada

(Table 1). Scallops were obtained from spring to fall with collections every $2 \mathrm{wk}$ during the period of gonad ripening and approximately weekly during spawning (Table 2). A sample consisted of about 30 scallops ( $-50 \%$ males and females) and was collected by SCUBA or by dredging with a 4-gang Digby drag. The overall mean size of scallops was $103 \pm 17.8 \mathrm{~mm}$ shell height ( $\mathrm{n}=9226$; range of sample means 98 to $125 \mathrm{~mm}$ ).

From 1978 to 1983, scallops were taken to the laboratory where only the gonad (with foot and crystalline style attached) and adductor muscle (meat) were dissected, weighed separately (wet weight, to the nearest $0.001 \mathrm{~g}$ ), placed in a convection oven to dry at about $80^{\circ} \mathrm{C}$ for $2 \mathrm{~d}$ (to a constant weight), and reweighed. Starting in 1984, a different method was adopted, whereby scallops were dissected into gonad, meat and remaining viscera, including foot and crystalline style. Individual body components were weighed wet, dried at $80^{\circ} \mathrm{C}$ for $2 \mathrm{~d}$, then reweighed. Shell height (to the nearest $\mathrm{mm}$ ) and sex were also recorded.

From April to November 1985, an additional 30 scallops from Tongue Shoal were collected on each sampling occasion for histological examination of the gonads and for comparison with the gono-somatic index (GSI). Gonads were dissected from the scallop and were fixed for at least $48 \mathrm{~h}$ in Bouin's fixative. After fixation, gonads were transferred to $70 \%$ ethanol until 
Table 1. Summary of Placopecten magellanicus sampling by year, month and site. $\mathrm{M}=$ Mascarene, $\mathrm{N}=\mathrm{Navy}$ Island, $\mathrm{T}=\mathrm{Tongue}$ Shoal, $W=$ Western Passage, $H=$ Hill's Point, $J$ = Joe's Point

\begin{tabular}{|c|c|c|c|c|c|c|c|c|c|c|c|c|}
\hline Year & Jan & Feb & Mar & Apr & May & Jun & Jul & Aug & Sep & Oct & Nov & Dec \\
\hline 1978 & - & $M N$ & $M N$ & $M N$ & $\mathrm{MN}$ & - & $M N$ & $M$ & $M N$ & M & $\mathrm{MN}$ & $M$ \\
\hline 1979 & $\mathrm{MN}$ & $\mathrm{MN}$ & $M N$ & $M N$ & $M N$ & M & $M N$ & $M N$ & $M N$ & $M N$ & $M N$ & $M$ \\
\hline 1980 & $\mathrm{MN}$ & $\mathrm{MN}$ & $\mathrm{MN}$ & M & $\mathrm{M}$ & $M N$ & $\mathrm{M}$ & $\mathrm{MN}$ & $M N$ & $\mathrm{M}$ & $N$ & $M$ \\
\hline 1981 & $\mathrm{MN}$ & $M$ & $M N$ & $M N$ & MN & $\mathrm{MN}$ & $\mathrm{MN}$ & $\mathrm{M}$ & - & $M N$ & $M N$ & $\mathrm{MN}$ \\
\hline 1982 & $M N$ & $M N$ & $\mathrm{MN}$ & $M N$ & $M N$ & $\mathrm{~N}$ & $M N$ & $M N$ & $M N$ & $M N$ & $N$ & $N$ \\
\hline 1983 & $\mathrm{MN}$ & $M N$ & $M N$ & $M N$ & $N$ & $\mathrm{~N}$ & $M N$ & $M N$ & $M N$ & $M N$ & - & $M$ \\
\hline 1984 & $\mathrm{MN}$ & $M N$ & - & $M N$ & - & $\mathrm{N}$ & $M$ & $M N$ & $\mathrm{M}$ & $M$ & $M$ & - \\
\hline 1985 & - & $M N$ & - & $M N$ & $\mathrm{~T}$ & $T$ & $\mathrm{~T}$ & $\mathrm{~T}$ & $\mathrm{~T}$ & $\mathrm{~T}$ & - & \\
\hline 1986 & - & - & - & - & $\mathrm{T}$ & $\mathrm{T}$ & - & $\mathrm{T}$ & $\mathrm{T}$ & - & - & - \\
\hline 1987 & - & - & - & - & - & $W N$ & WN & $W N$ & W N & - & - & - \\
\hline 1988 & - & - & $\mathrm{N}$ & H N & $\mathrm{HN}$ & $\mathrm{HN}$ & $\mathrm{HN}$ & $\mathrm{HN}$ & $\mathrm{HN}$ & - & - & - \\
\hline 1989 & - & - & - & $\mathrm{N}$ & $\mathrm{JN}$ & $\mathrm{J} T \mathrm{~N}$ & $\mathrm{~J} \mathrm{~T} \mathrm{~N}$ & $\mathrm{JTN}$ & $\mathrm{JTN}$ & $\mathrm{J} \mathrm{T} \mathrm{N}$ & - & - \\
\hline 1990 & - & - & - & 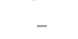 & $N$ & $\mathrm{~N}$ & $N$ & N & $N$ & - & - & - \\
\hline
\end{tabular}

further processing. Following standard dehydration, clearing and paraffin (Paraplast) embedding, samples were sectioned at $8 \mu \mathrm{m}$ thickness. Sectioned tissues were placed on slides and stained with haematoxylin/eosin (Humason 1972). Gonad tissue sections were staged according to Davidson \& Worms (1989).

The percent oocyte area was estimated by measuring the interfollicular tissue area and empty follicular area (lumen) from the histological gonad tissue sections for female scallops using the 'optical pattern recognition system' computer program by Biosonics Inc. at $32 \times$ magnification. The total area of the field for each measurement was $0.47 \mathrm{~mm}^{2}$ and 3 areas (fields) were examined per section (individual). The difference between field area and the interfollicular and empty follicular area represented the total oocyte area.

Data analysis. The GSI has been criticized as a technique for studying reproduction, especially for fish (deVlaming et al. 1982, Cayré \& Laloë 1986) and sea urchins (Gonor 1972). GSI should only be used for species with a highly seasonal reproductive cycle (Grant \& Tyler 1983), such as the giant scallop. GSI has been widely used to monitor the reproductive

Table 2. Sampling frequency by month for sites sampled from 1985 to 1990

\begin{tabular}{|lcccccc|}
\hline Site & Year & May & Jun & Jul & Aug & Sep \\
\hline Tongue Shoal & 1985 & 1 & 1 & 4 & 5 & 3 \\
Tongue Shoal & 1986 & 1 & 1 & - & 2 & 3 \\
Navy Island & 1987 & - & 2 & 2 & 5 & 2 \\
Western Passage & 1987 & - & 2 & 2 & 5 & 2 \\
Navy Island & 1988 & 2 & 3 & 2 & 5 & 2 \\
Hill's Point & 1988 & 2 & 3 & 2 & 5 & 2 \\
Navy Island & 1989 & 1 & 1 & 3 & 4 & 2 \\
Tongue Shoal & 1989 & - & 2 & 3 & 5 & 1 \\
Joe's Point & 1989 & 1 & 2 & 3 & 5 & 1 \\
Navy Island & 1990 & 1 & 2 & 4 & 5 & 2 \\
\hline
\end{tabular}

cycle in the giant scallop (Thompson 1977, Robinson et al. 1981, Barber et al. 1988), and Beninger (1987) found it to be effective in evaluating scallop reproductive activity in that the GSI cycle matched the histological pattern for the major spawning event. Barber \& Blake (1991) recommend the use of a GSI based on dry tissue weights, as water content can vary seasonally.

The gono-somatic index, based on dry tissue weight, was calculated as follows:

GSI $=($ gonad weight $/$ total soft body weight $) \times 100$

From 1978 to 1983, scallops were only dissected for gonad and muscle weights and a modified gonad index $\left(\mathrm{GSI}_{\mathrm{m}}\right)$ was calculated:

$\mathrm{GSI}_{\mathrm{m}}=$ (gonad dry weight $/$ muscle dry weight)

In order for the data from 1978 to 1983 to be comparable to the later years (1984 to 1990) a regression of $\log _{e}$ GSI on $\log _{e} G_{S I}$ using data obtained from samples collected from 1984 to 1988 was calculated: GSI = $37.71 \times \operatorname{GSI}_{m}{ }^{0.89}\left(r^{2}=0.99, n=1894, p<0.001\right)$. This relationship was then used to calculate GSI values for the 1978 to 1983 samples. GSI values and gonad weights from 1978 to 1983 were also adjusted for foot and crystalline style weight.

Statistical procedures (ANOVA, Duncan's Multiple Range test, pooled $t$-test) were performed on the GSI data using the SPSSx software package. Calculations and statistical analyses of GSI and gonad weights were based on mature scallops (>75 mm). An arcsin transformation was performed on percent oocyte area data prior to statistical analyses (ANOVA and Duncan's Multiple Range test). The frequency of spawning events was categorized by their occurrence with the different lunar phases for all sites from 1985 to 1990. The statistical methods of Batschelet (1981) were used 
to calculate a mean vector or 'direction' ( $\varnothing$ ) and dispersion $\left(\mathrm{S}_{1}\right)$. The Rayleigh test $\left(\mathrm{r}_{2 \mathrm{C}}\right)$ was used to test for randomness of spawning events in relation to the lunar phases. A bimodal model was used and corrections for grouping were made

\section{RESULTS}

\section{Annual cycle}

An annual reproductive cycle was evident from the long-term GSI pattern for the giant scallops from Passamaquoddy Bay (Fig. 2A). The initial increase in GSI commenced from mid-April to May with the highest GSI values occurring in July. Spawning, based on a drop in the GSI (Giese \& Pearse 1974. Barber \& Blake 1991), occurred from July through September, with the majority of gamete release occurring during August. The long-term seasonal cycle of gonad weight (for a $100 \mathrm{~mm}$ standardized scallop) was similar to that of the GSI (Fig. 2B). Gametogenic development, based on staging criteria from histological preparations of gonads from Tongue Shoal, 1985, supported the GSI data (from the same site) in that gonad development and filling occurred from April through June, peak ripeness was observed in July and spawning in August (Fig. 3).
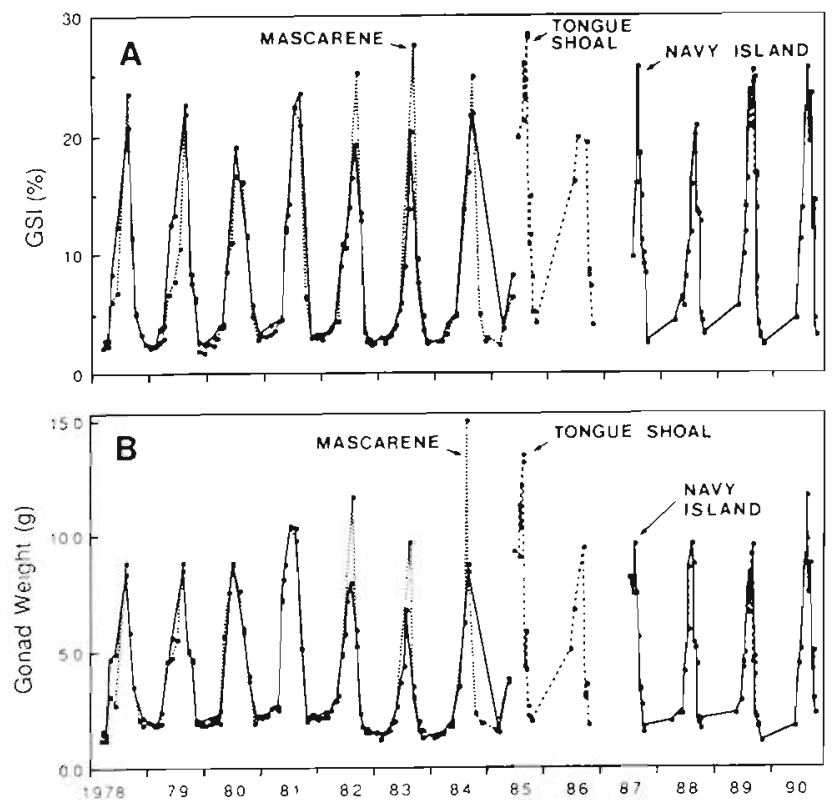

Fig. 2. Placopecten magellanicus. (A) Gono-somatic index (GSI) for giant scallops from 3 sites from 1978 to 1990. (B) Wet gonad weight for a giant scallop standardized to $100 \mathrm{~mm}$ shell height from 3 sites from 1978 to 1990

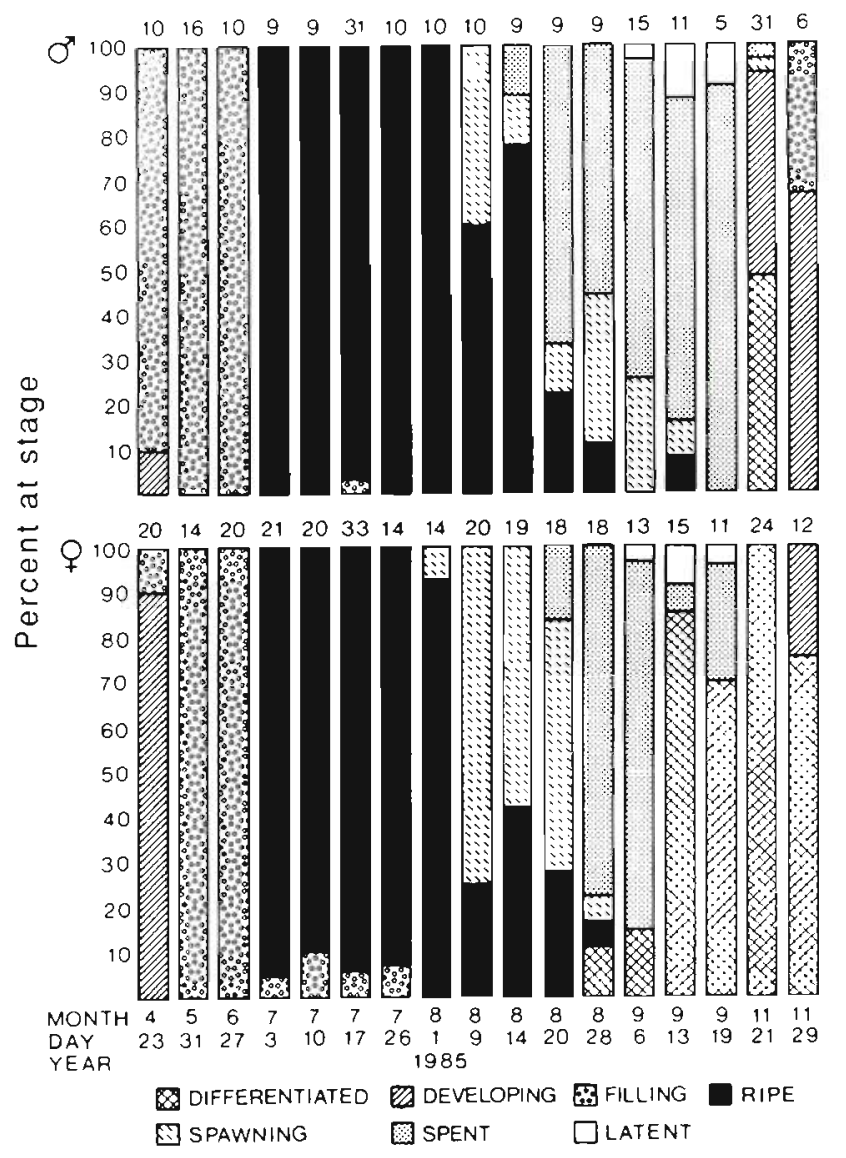

Fig. 3. Placopecten magellanicus. Gonad development cycle, illustrated as percentage of male (top) and female (bottom) giant scallops from Tongue Shoal, 1985, according to microscopic development stage. Numbers above bars indicate sample size

\section{Long-term pattern}

From 1978 to 1990 , the overall mean peak GSI for giant scallops from Passamaquoddy Bay was $22.0 \pm 8.0$ $(95 \% \mathrm{CI})$ and the annual mean of the GSI minima was $2.5 \pm 0.20$ (95\% CI). The 99th percentile of the highest GSI (July) values from all sites in Passamaquoddy Bay was $40 \%$

Annual mean GSI values derived from ripe scallops from the Mascarene site (1978 to 1984) ranged from $16.6 \%$ in 1980 to $27.5 \%$ in 1983 . These values were significantly different between years (ANOVA, $F=$ 8.19, $\mathrm{df}=6,210, \mathrm{p}<0.001$ ). From 1978 to 1990 , mean GSI values of ripe scallops varied from $19.0 \%$ in 1980 to $28.5 \%$ in 1985 for the Navy Island and Tongue Shoal sites. Annual mean GSI's were significantly different between years for the combined Navy Island and Tongue Shoal sites (ANOVA, $F=$ 5.85, $\mathrm{df}=12,409, \mathrm{p}<0.001)$ (no significant differ- 
ences were observed in GSI's between Navy Island and Tongue Shoal).

Annual peak gonad wet weights of a $100 \mathrm{~mm}$ standardized giant scallop ranged from a low of $8.7 \mathrm{~g}$ in 1980 to a high of $15.0 \mathrm{~g}$ in 1984 for Mascarene and from $6.7 \mathrm{~g}$ in 1983 to $13.5 \mathrm{~g}$ in 1985 for Navy Island and Tongue Shoal (Fig. 2B).

\section{Intra-annual pattern}

From 1985 to 1990, scallops were sampled every 2 wk during gonad ripening and about weekly during
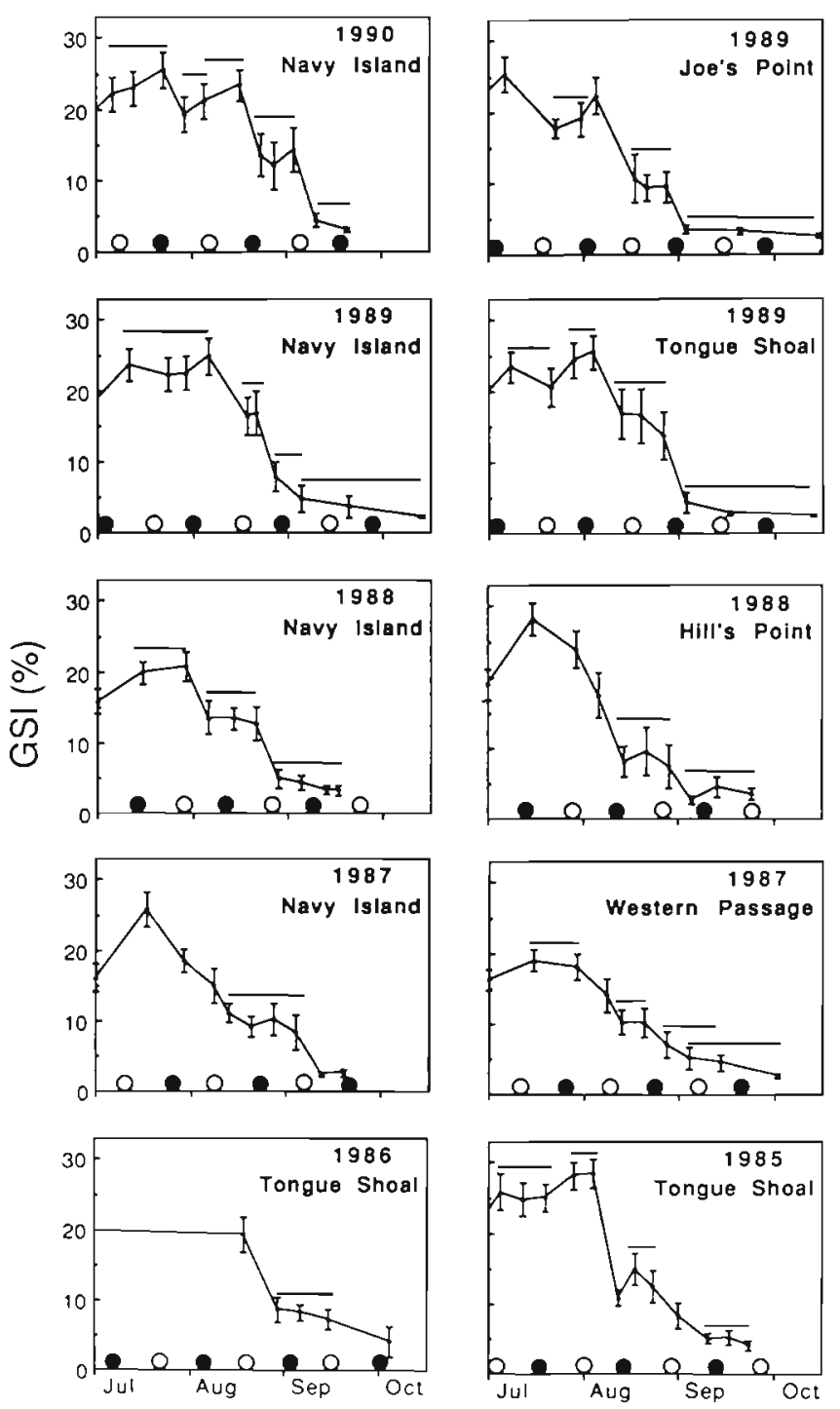

Fig. 4. Placopecten magellanicus. Gono-somatic index (GSI) of giant scallops from samples collected every 1 to $2 \mathrm{wk}$ in Passamaquoddy Bay (vertical bars indicate $95 \% \mathrm{CI}$, horizontal bars denotes no significant difference between adjacent sampling dates; Duncan's Multiple Range test, $p>0.05$ ).

(O) New moon, (•) full moon spawning. The decline in the mean GSI value following gonad ripening was not continuous but rather showed a stepwise pattern (Fig. 4). The GSI pattern of scallops from Joe's Point in 1989 and Navy Island in 1990 showed an initial period of decline followed by a brief increase, suggesting a possible minor spawning. The main spawning then followed about a month later. During this main period of decrease in mean GSI there was an intervening period of about 2 wk when no significant change in the GSI occurred (Duncan's Multiple Range test, $p>0.05$ ) (Fig. 4). This was then followed by a final period of decline to the annual minimum GSI (i.e. the trough). Observations on the GSI of individual scallops indicated that during the first main spawning period, the majority had partially spawned and none had completely spawned, until after the second period of decline.

Histological observations on the areal percentage of oocytes for scallops collected from Tongue Shoal in 1985 exhibited a similar intermittent pattern, in which after an initial release of eggs, there was an intervening period of a couple of weeks when there was no significant change in the density of oocytes (Duncan's Multiple Range test, $p>0.05$ ). This was followed by the second major release of gametes (Fig. 5).

The stepwise pattern of repeated decreases in GSI was observed at several sites in Passamaquoddy Bay all within the same year (e.g. Navy Island, Joe's Point, and Tongue Shoal for 1989) and over several years (1985 to 1990) (Fig. 4). The distribution of spawning events in relation to lunar phases was bimodal and most of the spawnings occurred prior to or on the new and full moons (Fig. 6). The distribution was significant, i.e. not random (Rayleigh test, $\left.r_{2 C}=0.479, n=22, p<0.01\right)$ and the mean vector $(\varnothing)$ or 'direction' was a line at $144^{\circ}$ and $324^{\circ}$ with respect to north or the new moon $\left(=0^{\circ}\right)$, with dispersion $\left(\mathrm{S}_{1}\right)=$

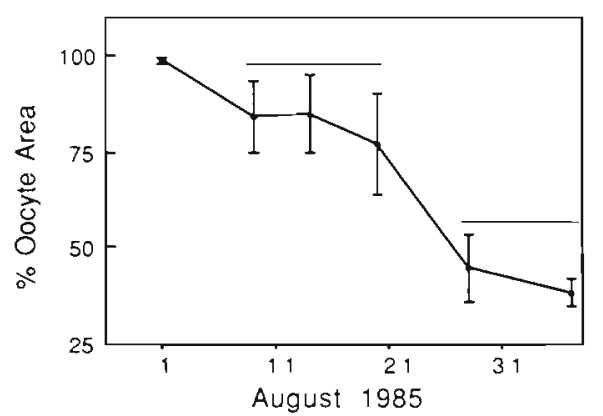

Fig. 5. Placopecten magellanicus. Percentage of oocytes per unit area of gonad during spawning season of the giant scallop from Tongue Shoal, 1985. (Vertical bars indicate $\pm 1 \mathrm{SD}$, horizontal bars denote no significant difference between adjacent sampling dates; Duncan's Multiple Range test, $\mathrm{p}>0.05$ ) 


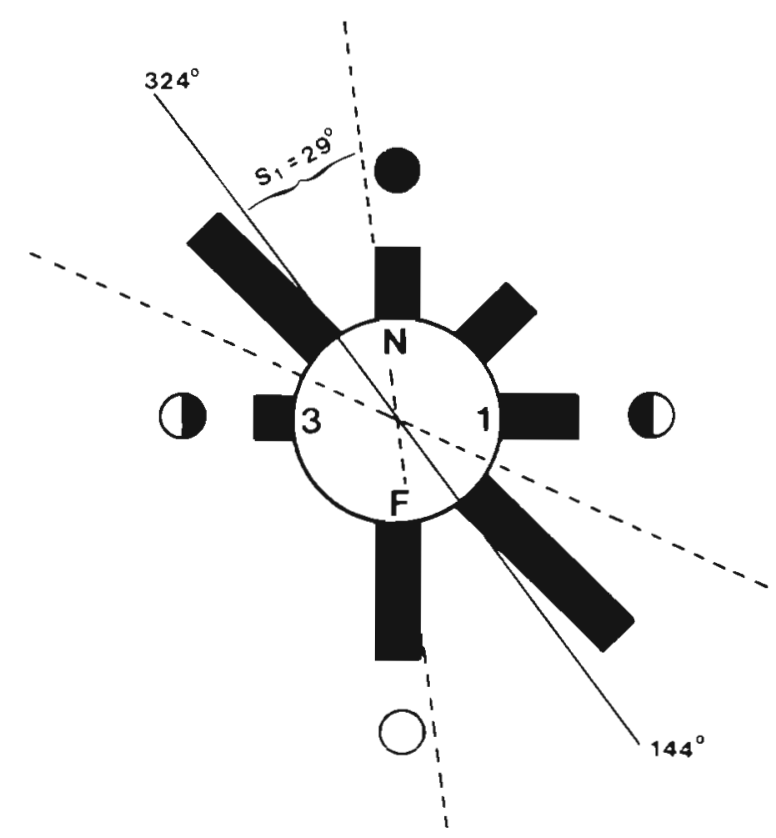

Fig. 6. Placopecten magellanicus. Relative frequency of spawning events in relation to the lunar cycle ( $n=22$ events), mean direction $\left(-; \varnothing=144^{\circ}\right.$ and $\left.324^{\circ}\right)$, and dispersion $\left(---; S_{1}=29^{\circ}\right) . N=$ new moon, $1=1$ st quarter, $F=$ full moon, $3=3$ rd quarter

$29^{\circ}$. In terms of the lunar cycle, the timing of these spawning events coincided with a period prior to the new and full moon phase, i.e. they were coincident with the period before the spring tides of the springneap tidal cycle (Fig. 6).

\section{Spatial pattern}

Comparisons of mean GSI of ripe scallops between Mascarene and Navy Island over the period 1978 to 1984 (Fig. 2A) showed that the GSI of scallops from the Mascarene site was significantly higher than that of Navy Island at an $\alpha=0.05$ but not at $\alpha=0.01$ (pooled $t$-test, $t=2.02, \mathrm{df}=563, \mathrm{p}<0.05$ ), and when these sites were examined by each year, Mascarene scallops were only significantly higher during 2 of the 7 yr $(1982, \mathrm{p}<$ $0.01 ; 1983, \mathrm{p}<0.01)$. Navy Island was higher in 1980 ( $\mathrm{p}$ $<0.01$ ) and no significant differences occurred in the other years. Comparison of mean GSI of ripe scallops between Navy Island and the various other sites from 1987 to 1989 revealed significant differences in 1987 (pooled $t$-test, $t=5.30, \mathrm{df}=68, \mathrm{p}<0.001$ ) and 1988 (pooled $t$-test, $t=5.09$, $\mathrm{df}=118, \mathrm{p}<0.001$ ) (Fig. 7). No significant differences occurred between scallops from Navy Island, Tongue Shoal and Joe's Point in 1989 (ANOVA, $F=2.85$, $d f=2,64, p>0.05$ ). A comparison of the onset of the main reproductive events (gonad
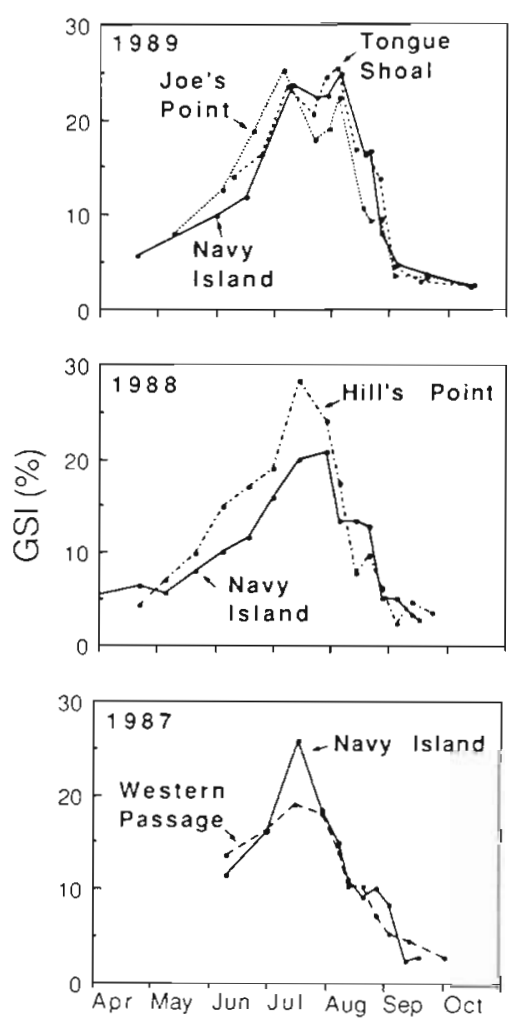

Fig. 7. Placopecten magellanicus. Comparison of gonosomatic index (GSI) of giant scallops from several sites within Passamaquoddy Bay, 1987 to 1989

ripening and spawning) between each of the different sites revealed a consistent pattern in timing for all of the years (Figs. 2A \& 7).

\section{Sexual pattern}

A comparison of mean GSI between the sexes during the period of gonad ripening (ca April to July) indicated that males were often higher than or occasionally equal to females (Fig. 8), and when the GSI for each sex was pooled over all sites and all years, males had a significantly higher index than females (pooled $t$-test, $t=4.53, \mathrm{df}=466, \mathrm{p}<0.001$ ). However, the timing of gonad ripening and spawning was similar between the sexes for all sites and years (Fig. 8).

\section{Spawning period}

Spawning period or duration was defined as the number of days from the start of spawning (decrease in GSI) to the end and included the periods in which no change in GSI occurred. The annual spawning period of scallops from the different sites in Passamaquoddy 

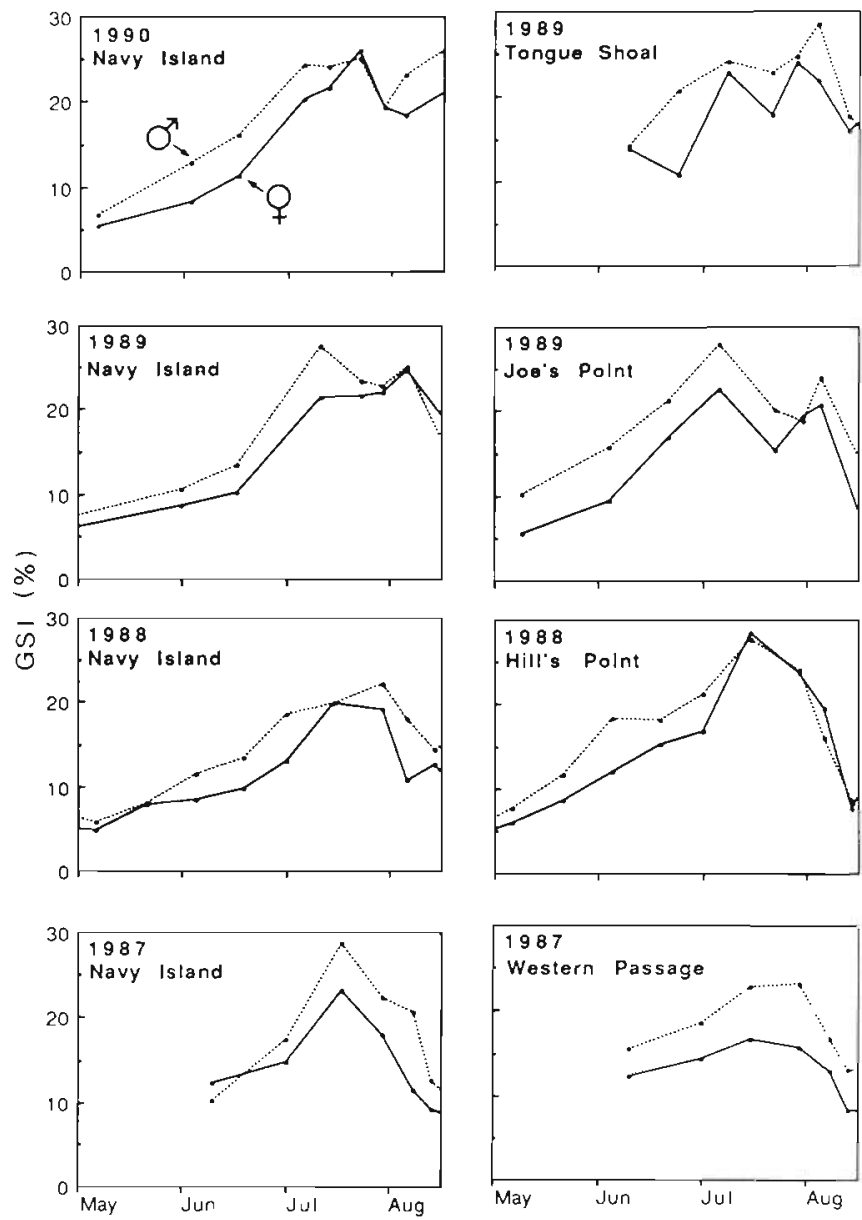

Fig. 8. Placopecten magellanicus. Gono-somatic index (GSI) of male and female giant scallops during the period of gonad ripening and spawning from several sites from 1987 to 1990

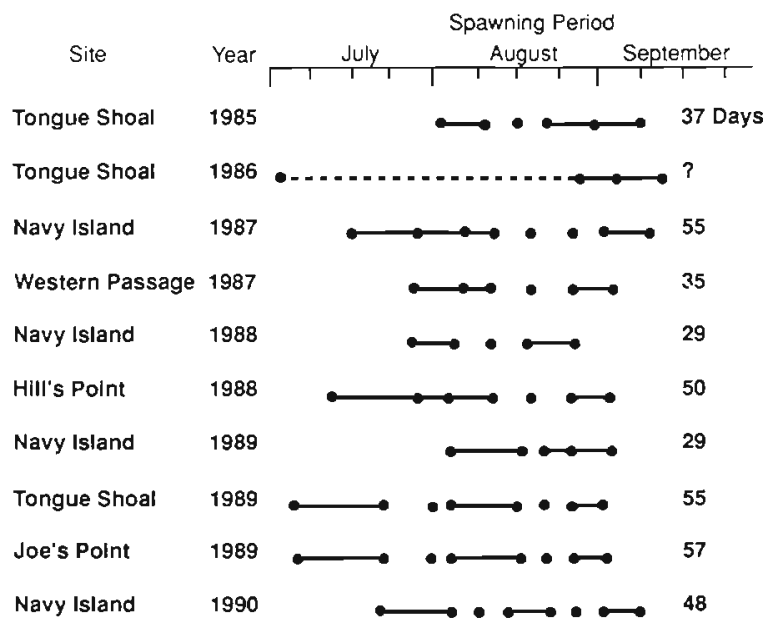

Fig. 9. Placopecten magellanicus. Annual spawning period of giant scallops from Passamaquoddy Bay from 1985 to 1990.

- indicates sample taken; --.-- indicates uncertain commencement of spawning for Tongue Shoal in 1986

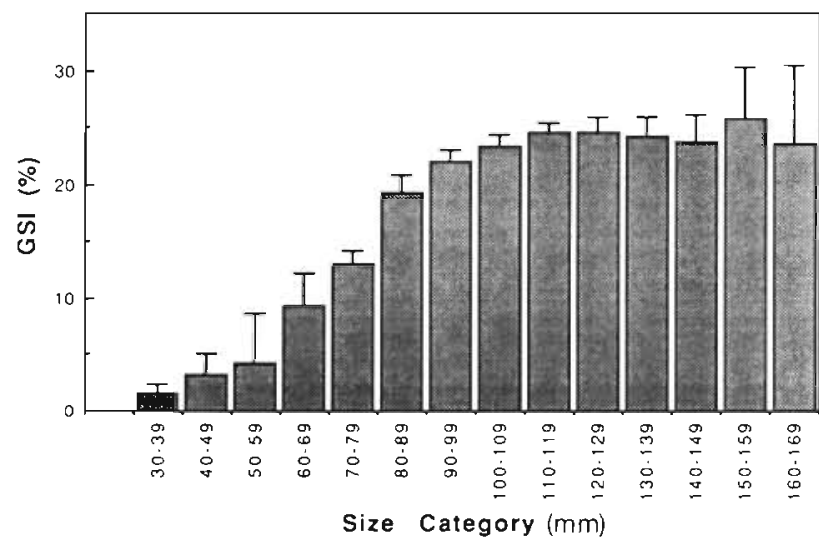

Fig. 10. Placopecten magellanicus. Gono-somatic index (GSI) of giant scallops by size class ( $10 \mathrm{~mm}$ shell height interval). All samples from July were pooled from 1978 to 1990. Vertical bars indicate $95 \% \mathrm{Cl}$

Bay varied from 29 to $55 \mathrm{~d}$ (Fig. 9). This range in values of the annual spawning period was only based on data obtained from scallops during the years 1985 to 1990 when the sampling regime was about weekly.

\section{Size at spawning}

GSI values by size class of scallops, sampled in July, showed a steady increase from $2.5 \%$ at the $30 \mathrm{~mm}$ size class up to $14 \%$ at $70 \mathrm{~mm}$ after which the larger scallops attained a plateau and GSI was independent of size (Fig. 10). Macroscopic examination of the gonads showed that scallops less than $40 \mathrm{~mm}$ could not be sexually differentiated on the basis of gonad colouration.

\section{DISCUSSION}

\section{Annual cycle}

The temporal pattern of gonad weight and GSI of giant scallops from Passamaquoddy Bay exhibited a discrete annual cycle. An annual reproductive cycle has been reported for giant scallops from Passamaquoddy Bay (Beninger 1987) and from other areas (Naidu 1970, Thompson 1977, Robinson et al. 1981. Barber et al. 1988, MacDonald \& Thompson 1988). A semiannual spawning cycle occurs in the southern part of its range (Dupaul et al. 1989, Schmitzer et al. 1991) and may occur on Georges Bank (Dibacco 1991). In Passamaquoddy Bay the spawning season commenced in early July through September but was mostly completed by the end of August. Previous studies carried out in Passamaquoddy Bay and the Bay of Fundy/Gulf 
of Maine system have reported spawning to occur from August to September (MacDonald \& Thompson 1986 , Beninger 1987) or later from September to October (Robinson et al. 1981, Barber et al. 1988, Tremblay \& Sinclair 1988). Only a few studies have reported spawning events occurring as early as July (Stevenson 1936, Welch 1950)

Scallops less than $40 \mathrm{~mm}$ could not be sexually differentiated by gonad colour, and furthermore, scallops less than this size had a GSI maximum of $2.5 \%$ which was equivalent to the GSI minima observed for adult scallops (Fig. 2A), suggesting that these scallops do not spawn. This corroborates earlier observations on giant scallops from Newfoundland (Naidu 1970) and inshore Maine (Langton et al. 1987). Scallops from the 40 to $70 \mathrm{~mm}$ size classes had gonads which could be sexually differentiated macroscopically and had peak GSI levels greater than $2.5 \%$, demonstrating that scallops in this size range could spawn. However, their lower GSI values suggest their overall reproductive contribution is very small. GSI becomes independent of size at about $80 \mathrm{~mm}$ and there was no evidence of reproductive senescence in animals in the size range examined in this study.

The spawning season in Passamaquoddy Bay, which occurred between July and September, encompassed a period of 29 to $55 \mathrm{~d}$. This does not imply that the population spawned continuously for $55 \mathrm{~d}$, as this estimate also included the period in which no change in GSI was observed and presumably no spawning occurred. Previous studies have reported spawning seasons as short as $4 \mathrm{~d}$ for a 'bed' on Georges Bank (Posgay \& Norman 1958) [although this was questioned by Naidu (1970)], to a protracted season of several months on scallop 'grounds' from deep-water populations of the Gulf of Maine (Barber et al. 1988), at Port au Port, Newfoundland (Naidu 1970), and on Georges Bank (Tremblay 1991). Calculating an accurate spawning period can be difficult as it is dependent, in part, on the frequency of the particular sampling schedule employed and the size of the sampling area (e.g. a 'patch', 'bed' or 'ground'; see Brand 1991 for definitions).

\section{Long-term pattern}

There are no previous studies on long-term reproductive cycles for scallops, even though such studies may provide important insights into the ecology of reproduction (Seed 1976). This work provides the longest record of the reproductive cycle for giant scallops Placopecten magellanicus.

From 1978 to 1984, significant annual differences were found in mean GSI maxima when sampling was approximately monthly. It was possible that scallops were not sampled at their peak ripeness, e.g. Navy Island in 1980, when no sample was obtained for the month of July. All other years are representative because once the population was fully ripe, by the end of June, maximum GSI levels were maintained for at least a few weeks (see Fig. 4), increasing the likelihood that sampling occurred during the peak. In 1985 to 1990, when samples were obtained every 1 to 2 wk, scallops were sampled at peak gonad ripeness and annual differences in GSI maxima were still observed.

The plethora of studies on scallop reproductive biology has resulted in a number of different approaches in quantifying the reproductive cycle. These include gonad weights (wet or dry) and indices based on gonad weight as a percentage of total soft body weight, muscle weight, somatic weight, shell height, or shell weight (Skreslet \& Brun 1969, Thompson 1977. Robinson et al. 1981, Beninger 1987, Wilson 1987. Paulet et al. 1988, Dupaul et al. 1989). For consistency a GSI using gonad weight/soft body weight would be most useful (Giese \& Kanatani 1987). Similar results have been found with giant scallop populations from Passamaquoddy Bay, inshore Maine, and the midAtlantic region when comparable methods were used (Beninger 1987, Barber et al. 1988, Dupaul et al. 1989.)

The annual range of GSI values for giant scallops from Passamaquoddy Bay at gonad ripeness was 16.6 to $28.5 \%$, and for gonad weight, 6.7 to $15.0 \mathrm{~g}$. This represents a maximum change of about 2 -fold. Longterm differences were observed in oysters Crassostrea virginica by Loosanoff (1965) and in black chiton Katharina tunicata by Giese (1969). The annual reproductive peak varied from 1.6 to $4.1 \mathrm{~mm}$ (gonad thickness) for oysters and from 6 to $11 \%$ (gonad index) for chitons. Both species exhibited a similar 2 -fold change in their respective indices, which is consistent with the differences for the giant scallop.

The GSI represents an approximation of the potential reproductive output. This differs from the actual reproductive output or zygote production as the latter is dependent, in part, on egg quality, occurrence of atreic oocytes, egg size, and adult density and size distribution (Lubet et al. 1987, Dorange et al. 1989, Levitan 1991). The 2 -fold range in potential reproductive output for giant scallops from Passamaquoddy Bay was less than the range in abundance observed at other life-history stages. For example, giant scallop spat studies carried out in Passamaquoddy Bay by Robinson et al. (1991) reported annual differences in spatfall as high as 3 times. Further, changes in the annual abundance of adult giant scallops, based on catch statistics which appear to reflect changes in recruitment, can differ by an order of magnitude (Dickie 1955, Caddy 1979). Thus, while annual varia- 
tion in the potential reproductive output probably does affect recruitment, the dominant factors influencing year class strength are operating at later life-history stages.

The maximum observed GSI for all giant scallops sampled from 1978 to 1990 in Passamaquoddy Bay was about $40 \%$. This represents the 'maximum reproductive level' for scallops from this area. We suggest that this parameter may be a population attribute which has both demographic characteristics and genetic properties. The $40 \%$ level for Passamaquoddy Bay, by being based on 13 yr of GSI data and encompassing a wide interannual range of environmental conditions, probably defines the upper limit of reproduction for this area, assuming that conditions stayed within the same range experienced in this work. The maximum reproductive level combined with the population mean GSI can be used as an index of sitespecific acute or long-term changes in environmental conditions (e.g. Donaldson 1990) or for comparisons with other populations or other species of scallops. The maximum reproductive level may also have application in broodstock selection studies as the maximum value for giant scallops from Passamaquoddy Bay.

\section{Intra-annual pattern}

Giese \& Kanatani (1987) have classified spawning patterns in marine invertebrates as partial and intermittent or complete. A partial and intermittent spawning is characterized by a continuous but periodic release of gametes, a series of small pulses in the emission of gametes, or the cessation of spawning with an incomplete release of all the gametes. Previous studies on Placopecten magellanicus show spawning to be complete (Thompson 1977, Robinson et al. 1981, MacDonald \& Thompson 1986, Beninger 1987, Dupaul et al. 1989) except for a minor late spring-early summer spawning seen in certain populations (Naidu 1970, Barber et al. 1988, MacDonald \& Thompson 1988). From our earlier monthly sampling (1978 to 1984 ) it also appeared that spawning was complete. However, a 1 to 2 wk sampling rate from 1985 to 1990 revealed the spawning pattern to be intermittent or pulsed. This was evident at all sites sampled. This has not been previously documented for $P$. magellanicus and may be due to a low sampling resolution (monthly) in previous work (e.g. Naidu 1970, Thompson 1977 , Robinson et al. 1981, Beninger 1987).

There was no evidence that the scallop population released all their spawn at once, but rather the main spawning pattern was 2-phase, with the majority of scallops releasing 40 to $60 \%$ of their gametes (based on the drop in GSI), followed by the release of all remaining gametes about 2 wk later. Data on the percent oocyte fullness and histological staging of the gonads also support the view that spawning at the population level was intermittent, with 2 periods of activity juxtaposing a period of no spawning.

At several sites in 1989 and 1990, there was evidence of an early partial spawning in July. The gonads appeared to have subsequently recovered (regenerated) rapidly before the main spawning event took place about a month later. This phenomenon of a small GSI or gonad weight reduction (spawning) and recovery prior to the main spawning was also seen in the scallops Chlamys opercularis, C. islandica, Amusium japonicum balloti, Pecten alba, and P. maximus (Taylor \& Venn 1979, Dredge 1981, Sundet \& Lee 1984, Sause et al. 1987, Paulet et al. 1988), and several other bivalve species such as green mussel Perna viridis, ribbed mussel Geukensia demissa, and northern quahog Mercenaria mercenaria (Lee 1988, Heffernan \& Walker 1989, Heffernan et al. 1989). An early spawning event may be a reproductive strategy of 'bet-hedging' whereby these species release a small portion of their gametes on the chance that the larvae may encounter favourable conditions for survival.

Spawning events in giant scallops from Passamaquoddy Bay were periodic and were significantly related to the lunar/tidal cycle. The mean 'direction' of spawning events occurred prior to the new and full moons (Fig. 6). This correspondence of a spawning event prior to the spring tides of the spring-neap tidal cycle suggests that a tidally related environmental variable may be an exogenous spawning cue. MacDonald \& Thompson (1988) have suggested that spawning is controlled by local conditions, and for giant scallops from Passamaquoddy Bay there exist several possible environmental spawning cues which could be correlated with the tidal cycle. These include physical (e.g. temperature, pressure, or currents), biological (e.g. food levels), and chemical factors (e.g. pheromones or exudates in the water columnj. Several possible spawning cues for Placopecten magellanicus have been suggested, including the moon (Naidu 1970) and the tides (Stevenson 1936, Dickie 1953). Lunar and tidally related spawning events have been reported in the scallops Pecten maximus and Chlamys (Pecten) opercularis (Amirthalingam 1928, Tang 1941, Mason 1958b) and in such subtidal bivalves as short yoldia Yoldia sapotilla, also from Passamaquoddy Bay (Battle 1932), and European oyster Ostrea edulis (Korringa 1947).

If the exogenous factor responsible for initiating spawning in the giant scallop is tidally related, we would expect spawning in ripe giant scallops from Passamaquoddy Bay to be a highly synchronous event. Spawning synchrony can be described in several 
different ways, such as intrapopulation synchrony, synchrony between the sexes, spatial synchrony (i.e. within the bay), as well as interannual synchrony. The relatively low variance in the GSI of giant scallops during spawning (e.g. Fig. 4) indicates there is a high degree of intrapopulation synchrony (Newell et al. 1982, Grant \& Tyler 1983, Barber et al. 1988, Paulet et al. 1988). Barber et al. (1988) found that individuals from an inshore site were more synchronized than a deep-water population in the Gulf of Maine and Schmitzer et al. (1991) reported a similar reduction in intrapopulation synchrony in giant scallops from the southern part of its range compared to the north. We found no evidence of an annual 'switch' in the intrapopulation spawning synchrony (constricted vs protracted) as suggested by Langton et al. (1987) for giant scallops from the Damariscotta River, Maine. Their observations could possibly be explained by an ephemeral or weak environmental stimulus during years with a protracted spawning at that inshore site. The absence of an appropriate cue, as mediated by habitat-specific food differences, resulted in a low spawning synchrony between individuals in some populations of Mytilus edulis (Newell et al. 1982). The timing of gonad maturation and spawning was highly synchronous between the sexes (Fig. 8). This seems to be evident for the giant scallop throughout its range (Robinson et al. 1981, MacDonald \& Thompson 1986, Beninger 1987. Schmitzer et al. 1991) as well as for other scallop species (Ansell 1974, Sundet \& Lee 1984, Sause et al. 1987). There was a high degree of spatial spawning synchrony within the bay. The onset of spawnings at Mascarene and Navy Island from 1978 to 1984 (Fig. 2A) and Navy Island and the other areas from 1987 to 1989 (Fig. 7) was similar. Spawning has been found to be synchronous between local populations of giant scallops from Newfoundland (MacDonald \& Thompson 1985) and for several other scallops (Skreslet \& Brun 1969, Taylor \& Venn 1979, Dredge 1981, Sause et al. 1987) but not for all species (Skreslet 1973, Bricelj et al. 1987). Finally, the timing of the onset and duration of spawning was similar from year to year, commencing in July and being effectively finished by the end of August. Beninger (1987) reported an annually consistent spawning period for giant scallops from Passamaquoddy Bay. Naidu (1970), however, found annual differences in the spawning season of giant scallops from Newfoundland. Thus, by all the above accounts, giant scallops from Passamaquoddy Bay exhibited a very high degree of spawning synchrony which appears to be achieved by having an exogenous environmental cue which occurs annually on a consistent and predictable basis.

The benefits which can accrue from a highly synchronous spawning in a gonochoristic broadcast spawner such as the giant scallop include an enhancement of gamete fertilization, thus ensuring the maximization of reproductive success (Franke 1986, Newell et al. 1982). As well, intrapopulation synchrony coupled with several short spawning events on a tidal/lunar periodicity will 'spread out the risk' of scallop larvae encountering unfavourable conditions, as opposed to epidemic spawning (Paulet et al. 1988, Lambert 1990). Enhanced larval survival by spawning in conjunction with possible elevated food levels due to advection or stratification (Balch 1981, Demers \& Legendre 1981, Parsons et al. 1983) is another possible advantage which could be conferred by spawning before the spring tides.

With the recently developed capability to sample and identify the early life-history stages (larvae, spat and juveniles) of the giant scallop (Naidu \& Cahill 1986. Tremblay et al. 1987, Dadswell et al. 1988), a sampling program to examine the relationships between these various life-history stages may help to further elucidate some of the processes of recruitment in the giant scallop. Future work could include the development of a spawning index based on larval scallop abundance, as is used by the Japanese (Ventilla 1982). A temporal study of size-related larval scallop abundance (as an indirect estimate of spawning period; Barber \& Blake 1991) could be used to test our hypothesis of a lunar/tidal intermittent spawning pattern. Finally, such studies in conjunction with settlement studies could be used to determine the relative contribution of larvae, from the different spawning events, to spatfall by testing if a similar pattern occurs in settlement (e.g. Brand et al. 1980).

Acknowledgements. We thank and greatly appreciate those who assisted with this project, especially B. Bradford, C. James, M. Lundy, J. Martin, D. Needler, M. Steward, J. Turner, and $N$. Witherspoon for the collection and processing of scallop samples, captains and crew of the MVs 'Pandalus II', 'Pandalus III' and ' $J$ L. Hart', A. Sreedharan and $K$. Stokesbury for statistical advice, and F. Cunningham and $W$. McMullon for graphic services. The comments of Drs D. E. Aiken, B. Barber, G. Harding, and E. Kenchington and an anonymous reviewer were most helpful in improving the manuscript. Data from 1978 to 1981 were collected as part of a scallop meat hydration project initiated by Dr G. Jamieson.

\section{LITERATURE CITED}

Amirthalingam, C. (1928). On lunar periodicity in reproduction of Pecten opercularis near Plymouth in 1927-28. J. mar. biol. Ass. U.K. 15: 606-641

Ansell, A. D. (1974). Seasonal changes in biochemical composition of the bivalve Chlamys septemradiata from the Clyde Sea area. Mar, Biol. 25: 85-99

Balch, W. M. (1981). An apparent lunar tidal cycle of phytoplankton blooming and community succession in the Gulf of Maine. J. exp. mar. Biol. Ecol. 55: 65-77 
Barber, B. J., Blake, N. J. (1991). Reproductive physiology. In: Shumway, S. E. (ed.) Scallops: biology, ecology and aquaculture. Elsevier, Amsterdam, p. 377-428

Barber, B. J., Getchell, R., Shumway, S., Schick, D. (1988). Reduced fecundity in a deep water population of the giant scallop Placopecten magellanicus in the Gulf of Maine, USA. Mar. Ecol. Prog. Ser. 42: 207-212

Batschelet, E. (1981). Circular statistics in biology. Academic Press, London

Battle, H. I. (1932). Rhythmic sexual maturation and spawning in certain bivalve mollusks. Contr. Can. Biol. Fish. 7: $257-276$

Beninger, P. (1987). A quantitative and qualitative study of the reproductive cycle of the giant scallop, Placopecten magellanicus, in the Bay of Fundy (New Brunswick, Canadaj. Can. J. Zool. 65: 495-498

Brand, A. R. (1991). Scallop ecology: distributions and behaviour. In: Shumway, S. E. (ed.) Scallops: biology, ecology and aquaculture. Elsevier, Amsterdam, p. 517-584

Brand, A. R., Paul, J. D., Hoogesteger, J. N. (1980). Spat settlement of the scallops Chlamys opercularis (L.) and Pecten maximus (L.) on artificial collectors. J. mar. biol. Ass. U.K. $60: 379-390$

Bricelj, V. M., Epp, J., Malouf, R. E. (1987). Intraspecific variation in reproductive and somatic growth cycles of bay scallops Argopecten irradians. Mar. Ecol. Prog. Ser. 36: $123-137$

Caddy, J. F. (1979). Long-term trends and evidence for production cycles in the Bay of Fundy scallop fishery. Rapp. P.-v. Réun. Cons, int. Explor. Mer 175: 97-108

Cayré, P., Laloë, F. (1986). Review of the gonad index (GI) and an introduction to the concept of its 'critical value': application to the skipjack tuna Katsuwonus pelamis in the Atlantic Ocean. Mar. Biol. 90: 345-351

Dadswell, M. J., Chandler, R. A., Parsons, G. J. (1988). Spat settlement and early growth of Placopecten magellanicus in Passamaquoddy Bay, Canada. J Shellfish Res. 7. $153-154$

Davidson, L. A., Worms, J. (1989). Stages of gonad development in the sea scallop, Placopecten magellanicus (Gmelin) based on both macroscopic and microscopic observation of the gametogenic cycle. Can. Tech. Rep. Fish. Aquat. Sci. No 1686

deVlaming, V., Grossman, G., Chapman, F. (1982). On the use of the gonosomatic index. Comp. Biochem. Physiol. 74A: $31-39$

Demers, S., Legendre, L. (1981). Mélange vertical et capacité photosynthétique du phytoplancton estuarien (estuare du Saint-Laurent). Mar. Biol. 64: 243-250

Dibacco, C. (1991). Considering a semiannual reproductive cycle for the sea scallop (Placopecten magellanicus) on Georges Bank. J. Shellfish Res. 10: 271-272

Dickie, L. M. (1953). Fluctuations in abundance of the giant scallop Placopecten magellanicus (Gmelin), in the Digby area of the Bay of Fundy. Ph.D. thesis, University of Toronto, Toronto, Ontario. Fish. Res. Bd Can. MS Rep. Biol. Sta. No. 526

Dickie, L. M. (1955). Fluctuations in abundance of the giant scallop Placopecten magellanicus (Gmelin), in the Digby area of the Bay of Fundy. J. Fish. Res. Bd Can. 12: 797-857

Donaldson, E. M. (1990). Reproductive indices as measures of the effects of environmental stressors in fish. Am. Fish. Soc. Symp. 8: 109-122

Dorange, G., Paulet, Y.-M, Le Pennec, M., Cochard, J-C. (1989). Critères histologique d'évaluation de la qualité des oocytes émis par Pecten maximus (Mollusque Bivalve). C. r. Acad. Sci. Paris 309 (série III): 113-120
Dredge, M. C. L. (1981). Reproductive biology of the saucer scallop Amusium japonicum balloti (Bernardi) in Central Queenslands waters. Aust. J. mar Freshwat. Res. 32: $775-787$

Dupaul, W. D., Kirkley, J. E., Schmitzer, A. C. (1989). Evidence of a semiannual reproductive cycle for the sea scallop Placopecten magellanicus (Gmelin, 1791), in the mid-Atlantic region. J. Shellfish Res. 8: 173-178

Franke, H.-D. (1986). The role of light and endogenous factors in the timing of the reproductive cycle of Typosyllis prolifera and some other Polychaetes. Am. Zool. 26. $433-445$

Giese, A. C. (1969). A new approach to the biochemical composition of the mollusc body. Oceanogr. mar. Biol. A. Rev. 7: $175-229$

Giese, A. C., Kanatani, H. (1987). Maturation and spawning. In: Giese, A. C., Pearse, J. S., Pearse, V. B. (eds.) Reproduction of marine invertebrates. Blackwell Scientific Publications, Palo Alto, p. 252-329

Giese, A. C., Pearse, J. S. (eds.) (1974). Introduction: general principles. In: Reproduction of marine invertebrates, Vol. 1. Academic Press, New York, p. 2-50

Gonor, J. J. (1972). Gonad growth in the sea urchin, Strongylocentrotus purpuratus (Stimpson) (Echinodermata: Echinoidea) and the assumptions of gonad index methods. J. exp. mar. Biol. Ecol. 10: 89-103

Grant, A., Tyler, P. A. (1983). The analysis of data in studies of invertebrate reproduction. I. Introduction and statistical analysis of gonad indices and maturity indices. Int. J. Invert. Reprod. 6: 259-269

Heffernan, P. B., Walker, R. L. (1989). Gametogenic cycles of three bivalves in Wassaw Sound, Georgia: III. Geukensia demissa (Dillwyn, 1817). J. Shellfish Res. 8: 327-334

Heffernan, P. B., Walker, R. L., Carr, J. L. (1989). Gametogenic cycles of three bivalves in Wassaw Sound, Georgia: I. Mercenaria mercenaria (Linnaeus, 1758). J. Shellfish Res. 8: $51-60$

Humason, G. L. (1972). Animal tissue techniques, 3rd edn W. H. Freeman and Company, San Francisco

Korringa, P. (1947). Relations between the moon and periodicity in the breeding of marine animals. Ecol. Monogr. 17 : $347-381$

Lambert, T C. (1990). The effect of population structure on recruitment in herring. J. Cons. int. Explor. Mer 47: $249-255$

Langton, R. W., Robinson, W. E., Schick, D. (1987). Fecundity and reproductive effort of sea scallops Placopecten magellanicus from the Gulf of Maine. Mar. Ecol. Prog. Ser. 37: $19-25$

Lee, S. Y (1988). The reproductive cycle and sexuality of the green mussel Perna viridis (L.) (Bivalvia: Mytilacea) in Victoria Harbour, Hong Kong. J. mollusc. Stud. 54: 317-325

Levitan, D. R. (1991). Influence of body size and population density on fertilization success and reproductive output in a free-spawning invertebrate. Biol. Bull. mar. biol. Lab., Woods Hole 181. 261-268

Loosanoff, V. L. (1965). Gonad development and discharge of spawn in oysters of Long Island sound. Biol. Bull. mar. biol Lab., Woods Hole 129: 546-561

Lubet, P., Besnard, J.-Y., Faveris, R., Robbins, I. (1987). Physiologie de la reproduction de la coquille SaintJacques (Pecten maximus L.). Océanis 13: 263-290

MacDonald, B. A., Thompson, R. J. (1985). Influence of temperature and food availability on the ecological energetics of the giant scallop Placopecten magellanicus. II. Reproductive output and total production. Mar. Ecol. Prog. Ser 25: $295-303$ 
MacDonald, B. A., Thompson, R. J (1986). Influence of temperature and food availability on the ecological energetics of the giant scallop Placopecten magellanicus. III. Physiological ecology, the gametogenic cycle and scope for growth. Mar. Biol. 93: 37-48

MacDonald, B. A., Thompson, R. J. (1988). Intraspecific variation in growth and reproduction in latitudinally differentiated populations of the giant scallop Placopecten magellanicus (Gmelin). Biol. Bull. mar. biol. Lab., Woods Hole 175: 361-371

MacDonald, B. A., Thompson, R. J. Bayne, B. L. (1987). Influence of temperature and food availability on the ecological energetics of the giant scallop Placopecten magellanicus. IV. Reproductive effort, value and cost. Oecologia 72: $550-556$

MacKenzie, C. L. Jr, Merrill, A. S., Serchuk, F. M. (1978). Sea scallop resources off the Northeastern U.S. coast, 1975. Mar. Fish. Rev. 40: 19-23

Mason, J. (1958a). The breeding of the scallop, Pecten maximus (L.), in Manx waters. J. mar. biol. Ass. U.K. 37 : $653-671$

Mason, J. (1958b). A possible lunar periodicity in the breeding of the scallop. Pecten maximus (L.). Ann. Mag. nat. Hist. (Ser. 13) 1: 601-602

Naidu, K. S. (1970). Reproduction and breeding cycle of the giant scallop Placopecten magellanicus (Gmelin) in Port au Port Bay, Newfoundland. Can. J. Zool. 48: 1003-1012

Naidu, K. S., Cahill, F M. (1986). Culturing giant scallops in Newfoundland waters. Can. MS Rep. Fish. Aquat. Sci. No. 1876

Newell, R. I. E, Hilbish, T J., Koehn, R. K., Newell, C. J. (1982). Temporal variation in the reproductive cycle of Mytilus edulis L. (Bivalvia, Mytilidae) from localities on the east coast of the United States. Biol. Bull. mar. biol. Lab., Woods Hole 162: 299-310

Parsons, T. R., Perry, R. I., Nutbrown, E. D., Hsieh, W., Lalli, C. M. (1983). Frontal zone analysis at the mouth of Saanich Inlet, British Columbia, Canada. Mar. Biol. 73: 1-5

Paulet, Y M., Lucas, A., Gerard, A. (1988). Reproduction and larval development in two Pecten maximus (L.) populations from Brittany. J. exp. mar. Biol. Ecol. 119: 145-156

Posgay, J. A. (1957). The range of the sea scallop. Nautilus 71 : $55-57$

Posgay, J. A., Norman, K. D. (1958). An observation on the spawning of the sea scallop, Placopecten magellanicus (Gmelin), on Georges Bank. Limnol. Oceanogr. 3: 478

Robinson. A. M., Breese, W. P. (1984). Spawning cycle of the weathervane scallop Pecten (Patinopecten) caurinus Gould along the Oregon coast. J. Shellfish Res. 4: 165-166

Robinson, S. M. C., Martin, J. D., Chandler, R. A., Parsons, G. J (1991). Spatial patterns of spat settlement in the sea scallop, Placopecten magellanicus, compared to hydrographic conditions in Passamaquoddy Bay, New Brunswick, Canada. J. Shellfish Res, 10: 272-273

Robinson, W. E., Webling, W. E., Morse, P., McLeod, G. C. (1981). Seasonal changes in soft-body component indices and energy reserves in the Atlantic deep-sea scallop, Placopecten magellanicus. Fish. Bull. U.S. 79: 449-458

Sastry, A. N. (1970). Reproductive physiological variation in latitudinally separated populations of the bay scallops, Aequipecten irradians Lamark. Biol. Bull. mar. biol. Lab., Woods Hole 138: 56-65

Sause, B. L., Gwyther, D., Hanna, P. J., O'Connor, N A (1987). Evidence for winter-spring spawning of the scallop
Pecten alba (Tate) in Port Phillip Bay, Victoria. Aust. J mar. Freshwat. Res. 38: 329-337

Schmitzer, A. C., Dupaul, W. D., Kirkley, J. E. (1991). Gametogenic cycle of sea scallops (Placopecten magellanicus (Gmelin, 1791)) in the mid-Atlantic Bight. J. Shellfish Res. 10: $221-228$

Seed, R. (1975). Reproduction of Mytilus (Mollusca: Bivalvia) in European waters. Pubbl. Staz. zool. Napoli 39 (Suppl.): $317-334$

Seed, R. (1976). Ecology. In: Bayne, B. L. (ed.) Marine mussels their ecology and physiology. Cambridge University Press, Cambridge, p. 13-65

Shafee, M. S., Lucas, A. (1980). Quantitative studies on the reproduction of black scallop, Chlamys varia (L.) from Lanveoc area (Bay of Brest). J. exp. mar. Biol. Ecol. 42: $171-186$

Skreslet, S. (1973). Spawning in Chlamys islandica (O. F. Müller) in relation to temperature variations caused by vernal meltwater discharge. Astarte 6: 9-14

Skreslet, S., Brun, E. (1969). On the reproduction of Chlamys islandica (O. F. Müller) and its relation to depth and temperature. Astarte 2: 1-6

Stevenson, J. A. (1936). The Canadian scallop - Its fishery, life-history, and some environmental relationships. M.A. thesis, University of Western Ontario, London, Ontario. Fish. Res. Bd Can. MS Rep. Biol. Sta. No. 373

Sundet, J. H., Lee, J. B. (1984). Seasonal variations in gamete development in the Iceland scallop. Chlamys islandica. J. mar. biol. Ass. U.K. 64: 411-416

Tang, S.-F. (1941). The breeding of the escallop (Pecten maximus (L.)] with a note on the growth rate. Proc. Trans. Liverpool biol. Soc. 54: 9-28

Taylor, A. C., Venn, T. J. (1979). Seasonal variation in weight and biochemical composition of the tissues of the Queen scallop, Chlamys opercularis, from the Clyde Sea area. J. mar. biol. Ass. U.K. 59: 605-621

Thompson, R. J. (1977). Blood chemistry, biochemical composition, and the annual reproductive cycle in the giant scallop, Placopecten magellanicus, from southeast Newfoundland. J. Fish. Res. Bd Can. 34: 2104-2116

Tremblay, M. J. (1991). Sea scallop larvae Placopecten magellanicus in the Georges Bank region: distribution, abundance and condition. Ph.D. thesis, Dalhousie University, Halifax, Nova Scotia

Tremblay, M. J., Meade, L. D., Hurley, G. V (1987). Identification of planktonic sea scallop larvae (Placopecten magellanicus) (Gmelin). Can. J. Fish. Aquat. Sci. 44: $1361-1366$

Tremblay, M. J., Sinclair, M. (1988). Vertical and horizontal distribution of sea scallop (Placopecten magellanicus) larvae in the Bay of Fundy in 1984 and 1985. J. Northwest Atl. Fish Sci. 8: 43-53

Trites, R. W. Garrett, C. J. R. (1983). Physical oceanography of the Quoddy region. Can. Spec. Publ. Fish. Aquat. Sci. 64: $9-34$

Ventilla, R. F. (1982). The scallop industry in Japan. Adv. mar. Biol. 20: 309-382

Welch, W. R. (1950). Growth and spawning characteristics of the sea scallop, Placopecten magellanicus (Gmelin) in Maine waters. M.Sc. thesis, University of Maine, Orono

Wilson, J H. (1987). Spawning of Pecten maximus (Pectinidae) and the artificial collection of juveniles in two bays in the west of Ireland. Aquaculture 61: 99-111

Manuscript first received: July 30, 1991

Revised version accepted: January 9, 1992
This article was presented by G. C. Harding, Dartmouth, Nova Scotia, Canada 